\title{
RESILIENT DIGITAL FINANCIAL EDUCATION FOR YOUTH - EUROPEAN MONEY QUIZ PROJECT
}

\author{
Sladjana Sredojevićc ${ }^{*}$, \\ Sophia Ziakou ${ }^{2}$ \\ ${ }^{1}$ Head of Bank Training Center \\ and Specialist for International \\ Cooperation, IFIs and Education in \\ the Association of Serbian Banks, \\ Belgrade, Serbia \\ ${ }^{2}$ Special Advisor at the Hellenic \\ Bank Association, \\ Athens, Greece
}

\begin{abstract}
:
The subject of this paper is the analysis of the European Money Quiz, as a digital learning initiative, as a direct response to the sustainable and resilient digital education for youth. Although the platform uses the digital form, in the center of this initiative are children, their engagement and improvement of their financial literacy. In order to illustrate that, additional analysis is conducted at the country level, from the perspective of two national banking associations from the Southeast Europe region: Serbia and Greece. The aim is to show how European Initiative in digital platform brings resilience to different concepts of organization of education for youth in two countries. Such a disclosure of best practices and experiences, should help policy makers and practitioners to provide proper supply in proper time, including (re)evaluation or upgrade of the existing programs and consideration of new priorities, target groups and topics (local context).
\end{abstract}

\section{Keywords:}

financial education, digitalization, youth, banking.
Correspondence:

Sladjana Sredojević

\section{INTRODUCTION}

A more robust, safe, digitally transformed, and transparent banking and financial services sector needs responsible consumers who are actively participating in improving their financial awareness, knowledge and well-being. Financial Education supports efforts of consumers to be properly informed in the decision-making process on choosing intelligent, appropriate, and suitable financial products. Given the importance of developing young people's financial literacy skills and current policy efforts to introduce this subject in the school and/or to introduce national strategy on Financial Education, developing and introducing new tools for financial education of young people is inevitable action both for public and for private sector - Banking and Financial services sector as the active stakeholder. One of the target groups of this segment of population - pupils 13 to 15 years old is subject to regular evaluation of financial literacy level with the Program for International Student Assessment - PISA implemented by the Organization for Economic Cooperation and Development. A robust measure of the financial literacy of 15-year-old students provides information that can indicate whether the current approach to financial education is effective (OECD, 2014). This Paper as an empirical study is presenting one digital/online Projects of the united banking sector of Europe as its direct contribution to the continuous, sustainable and resilient financial education of young students aimed to give positive impact on effectiveness of current approaches in the public sector in this field. 


\section{LITERATURE REVIEW}

According to the Organization for Economic Co-operation and Development (OECD), following definition of financial education is often used: "Financial Education is the process by which financial consumers/investors improve their understanding of financial products and concepts and, through information, instruction and/or objective advice, develop the skills and confidence to become more aware of financial risks and opportunities, to make informed choices, to know where to go for help, and to take other effective actions to improve their financial well-being" (OECD, 2020, pp 26).

The European Banking Authority (EBA) published its second edition of the Financial Education Report - FER (EBA, 2020) in 2020. The Report is based on the EBA financial education repository, which identifies, for example, that awareness-raising campaigns remain among the key tools used by national authorities to reach wide audiences and, in certain cases, to alert consumers to potential risks they may face regarding the use of financial products and services (e.g. crypto-assets). In addition, it highlights the increasing role of financial innovation and the growing focus on specific target groups for financial education and literacy initiatives, such as children, youth and elderly. "An analysis of the repository reveals that the majority of the 123 initiatives reach their audience by means of online resources. This exemplifies the significant role that online (digital) tools play in financial education today, which is in accordance with the broader general trend towards digitalization of the society." (EBA, 2020).

The literature which currently exists surrounding the use of digital technology in education outlines the ways in which it is currently used and the practices which teachers are currently using. Authors like Liu, Navarrese and Wivagg (2014) have demonstrated that mobile devices like the iPod touch can provide English Language Learners with significant support for language and content learning, and extend learning time from classroom to home. Koszalka and Ntloedibe-Kuswani (2010) review a broad range of case studies which research the various educational applications of applying mobile technology within a classroom environment, concluding that the benefits of mobile learning are not yet understood from the perspective of whether technology is safe or disruptive to use. At the same time, the issue of accessibility of digital an online technology for financial education is open and there is still a lot of work to do in order to make digital technology easily accessible to students and this is something which school administrators need to continue to focus on. As per the findings of the research study done by Neha (2016), it was found that digital technology does help teachers to teach financial literacy to students in elementary schools. Overall, it is a tool which has shown to be effective for student learning.
The study concludes that a combination of these two areas of interest is certain to provide students an enlightening learning experience.

Methodology used in this empirical study is relying on several methods: synthesis, analysis, method of comparison and analogy, method of description and interviews. Research objective is to demonstrate that initiatives towards financial resilience are manageable even in turbulent times when digital tools (financial technologies) that are supporting financial education can bring great added value to the level of financial literacy of youth.

\section{DIGITALIZATION AND FINANCIAL EDUCATION IN TURBULENT TIMES}

Current conditions of life and work are characterized by rapid technological changes. Modern society, known as a digital age, is already largely conquering the elements of the fourth industrial revolution and is already based on accelerated digitalization paving the way for the application of technology in science, economics and many other fields. The role of digitalization is going much more beyond these; namely, it is expected that technology and digital innovations will help governments in better and faster implementation of Sustainable Development Goals, climate change targets and other relevant national development goals. However, although variety of digital financial services easily accessible are constantly being provided (supply side), we should not neglect, at the same time, the interests and satisfaction of clients or service users which cannot be achieved without proper level of their information, education and capability to make sustainable and resilient financial decisions (demand side).

The need to educate young people in the field of financial services, economy and finance - various disciplines integrated in the financial education activities - is growing, particularly having in mind the natural inclination of this segment of population in their use of digital tools. It is not an exaggeration to say that the youth of today spend more time watching television and using digital technology such as smartphones, iPads, tablets, laptops than they do running around or playing outdoors (Neha, 2016). In addition to that, financial literacy is a topic which is not being compulsory taught to elementary school students in most of the countries despite the importance and relevance it holds in everyday life. Therefore, enabling young population to have an access to technology brings potential to transform the way students learn, enhance their knowledge and apply technology in ways that will positively transform their future decisions in life. 


\section{EUROPEAN INITIATIVE IN BANKING SECTOR AS A DIGITAL EDUCATION TOOL}

\subsection{European Money Quiz - European Perspective}

European Money Quiz (EMQ) is a digital learning initiative dedicated to children and youth. It is the result of the common effort of thirty-two National Banking Associations under the coordination of the European Banking Federation $(\mathrm{EBF})^{1}$ in order to:

- address and improve the financial literacy level of students 13-15 years old, and

- prepare them for the class competitions to be held at national and European level.

EMQ was carefully designed by the Financial Education Project Group (FEPG) ${ }^{2}$ of EBF and it is part of EBF commitment to provide consumers with a more sound understanding of financial services.

From its launch in 2018, EMQ was successfully implemented and even won the prize for the best 2018 Trade Body Campaign in Europe in the Brussels awards ceremony hosted by the UK-based Public Relations and Communications Association (PRCA) ${ }^{3}$. Its success and acceptance lie on the fact that it is an online well-structured educational tool for students and teachers using the 'fun/gaming' element. EMQ comes with a toolkit, which includes sample questions, practice quizzes, teacher's instructions as well as videos, info-graphics and other materials that are all available online $e^{4}$ to national coordinators also in the language of their country ${ }^{5}$ making full use of digitalization tools. Moreover, the quizzes are displayed on Kahoot, a Norway-based online quiz platform, which is already used in millions of classrooms worldwide and can be available to students also for personal practice 24/7.

Another basic element for EMQ recognition was the fact that EBF inserted the element of competition for the students (National and European Finals).

1 EBF is the voice of the European banking sector, uniting 32 national banking associations in Europe that together represent some 3,500 banks large and small, wholesale and retail, local and international - employing about two million people. For more information visit: www.ebf.eu.

2 FEPG is the project group of EBF which works on financial education. It is composed by the representatives from National Banking Associations, members of EBF, with the scope of gathering good practices, running surveys and reports, creating educational materials, etc. Among the projects of FEPG is also the establishment of the institution of the European Money Week (EMW) which was first launched in 2015 and takes part each year in April. From 2019 the European Money Week is aligned with the Global Money Week (GMW) which is under the auspices of OECD.

3 PRCA jury, consisting of European public affairs professionals, praised the European Money Quiz as a project that managed to make a significant impact on a relatively low budget. For more information https:// www.ebf.eu/ebf-media-centre/european-money-quiz-initiative-wins-paaward-in-brussels

4 The special dedicated section on the website of EBF is https://www.ebf.eu/ europeanmoneyquiz/.

5 Almost all National Banking Associations have created special sections on their website for EMQ.
Every member of EBF, National Banking Association, was responsible to formulate a national competition, the winners of which would represent the country to the European Finals, with physical presence in Brussels. The prize for becoming a National Champion and the possibility to become the European Champion of EMQ gave students extra motivation.

On a national level, the option of hosting the finals in live-streaming via YouTube with the questions appearing directly on smart-boards or displays in classrooms helps national Banking Associations to access more schools in more dispersed areas without the need of physical movement or organization of local written or oral examinations. In Live-streaming the answers are given directly online, allowing each classroom to see how well it competes against others in their country as soon as the quiz is ended. On European level the finals are conducted with physical presence in order to provide the students with a complete educational experience (2-days-activities program). All national winners compete with each other simultaneously in their native language on the same thirty financial literacy questions having the feeling of equal participation. The questions address topics such as saving, debt, investment, compound interest, inflation and also cyber-security. The European Champion is announced straight after the end of the competition in a beautiful ceremony.

The global pandemic (Covid 19) context and national lock-down measures posted a severe setback for EMQ in 2020. National coordinators reported to EBF that classroom participation dropped down considerably due to the closure of schools because of sanitary measures. Additionally, restrictions in traveling and gathering of people prohibited the realization of the European Finals in Brussels. But thanks to the innovative teaching methods ${ }^{6}$ behind the EMQ it was made possible, on the one hand, for the teachers to reach out to their students at home and easily integrate EMQ in their online teaching programs and, on the other hand, for national banking associations to conclude their national finals. Also, EBF used the tool of live streaming as an alternative to the European Championship in Brussels. Thus, despite the global pandemic context, as seen in table below, the EMQ European Finals were live streamed on June $16^{\text {th }}, 2020$, with the participation of 28 countries $^{7}$ with 22 national champions. Kahoot, also recorded five times more sessions played than the previous years.

6 Live-streaming options on YouTube and Kahoot Quiz platform.

7 The countries are in alphabetical order: Albania, Austria, Azerbaijan, Belgium, the Czech Republic, Denmark, Estonia, Finland, Germany, Greece, Hungary, Iceland, Ireland, Italy, Latvia, Liechtenstein, Lithuania, the Netherlands, North Macedonia, Norway, Poland, Portugal, Romania, Serbia, the Slovak Republic, Slovenia, Spain and Sweden. 
Table 1. EMQ European Competition

\begin{tabular}{lcclc}
\hline Year & Countries & Languages & Pondium & Kahoots plays \\
\hline 2018 & 27 & 24 & Poland, Ireland, Germany & 45.000 \\
\hline 2019 & 28 & 26 & Slovenia, North Macedonia, Germany & 100.000 \\
\hline 2020 & $28^{*}$ & 22 & Everybody & 500.000 \\
\hline
\end{tabular}

* 23 national finals. Albania, Belgium, Azerbaijan, Estonia and Lichtenstein had to cancel their national finals.

Source: $\mathrm{EBF}$

EBF reaffirmed its commitment to support and promote EMQ. The 2021 competition is designed to be concluded in April 2021. It is amazing to realize that an online game can be used to inform and engage students to learn in a funny way about personal finance and difficult financial terminology. For the banking sector the promotion of financial education is a core priority, a true commitment to provide consumers, current and potential, with a more sound understanding of financial services and digitalization has to be used on that behalf.

\subsection{European Money Quiz - perspective of selected countries}

European nature of the EMQ project is an outstanding value. Developed jointly by almost 30 national banking associations from Europe (centripetal), this project also has various special characteristics since it is being locally implemented (centrifugal), adapted and applied with different approaches. Following sections will analyze differences and similarities in local implementation of the EMQ project as an online educational tool in two territorially close but geographically different countries of the South East Europe - Serbia and Greece.

\section{Serbia - Serbian Bank Association}

Republic of Serbia is a landlocked country in the central part of the Balkan Peninsula, South East Europe. In Serbia, there is no national strategy for financial education and financial literacy is included only as an inter-competencies subject in the school curriculum.

Having that in mind, Association of Serbian Banks (ASB) as the national banking association representing all banks operating in Serbia since its establishment in 1921, have decided to support national financial education efforts by joining European Initiatives launched by the EBF - European Money Week and European Money Quiz. Success achieved within engagement in the FEPG of the EBF, and experience gained, was the starting point in initiation of the ambitious plan of the Financial Education of the ASB and its members banks. Beside local initiation of the European Money Week, launching the Project of European Money Quiz in 2018 represented additional strategic, socially responsible and very popular initiative in public, media, schools, teachers, students. Visibility gained contributed to many other ASB and brought additional relevance reflected in some new strategically important projects that followed; one of them was the Project of the Government of the Republic of Serbia of Introduction of the Financial Literacy in the Educational System of the Republic of Serbia, in which ASB's national coordinator of the $\mathrm{EMQ}^{8}$ became a member of the national strategic Project team. The approach in implementation of the EMQ in Serbia since 2018 was based on the cooperation with the Ministry of Education of the Republic of Serbia, who supported the EMQ by officially inviting all schools operating in Serbia to join the quiz with their pupils (13-15 years old). This approach was followed later on, as a good practice, by some other countries in Europe. EMQ was held since 2018 regularly, with a very positive media back up. Year 2020 was challenging, due to the fact that schools closed on March $16^{\text {th }}, 2020$ which was just a day before a national competition scheduled for March $17^{\text {th }}, 2020$. Despite such an extraordinary obstacle, competition was held via Kahoot and YouTube platform on agreed date, but with a reduced number of pupils who participated. Table 2 below represents statistics on the EMQ in the Republic of Serbia:
8 Both authors are National Coordinators of the Project of the EMQ in their respective countries (Serbia - S.Sredojevic, Greece - S.Ziakou). 
Table 2. EMQ in Serbia

\begin{tabular}{llcll}
\hline Year & Date & Classrooms & Schools & Kahoots plays \\
\hline 2018 & 16.03 & $77^{\star}$ & 51 & 154 pupils \\
\hline 2019 & 27.03 & & 157 & 551 pupils \\
\hline 2020 & 17.03 & 107 & 250 (out of 590 registered) \\
\hline
\end{tabular}

* This year, invitations have been sent out to the classrooms. In the next years, participation and competition will be allowed to individual students directly.

Source: ASB

Beside its benefits for pupils, schools and banking sector, as main stakeholders, EMQ in Serbia is a direct contribution of the banking sector to the effort of the Government of Serbia in improving the level of financial literacy of students (13 to 15 years old) who are target group for future PISA assessment, too.

\section{Greece - Hellenic Bank Association}

Greece is a country located in South-eastern Europe at the crossroads of Europe, Asia and Africa. It is a country with special characteristics as it has the longest coastline on the Mediterranean Basin and 11th longest coastline in the world in length, featuring many islands of which 227 are inhabited, while mainland is at eighty percent mountainous. All these features make Greece unique but at the same time impose great barriers in everyday life. In Greece there is no national strategy for financial education, and financial literacy is included only as a sub-subject in the school curriculum.

The Hellenic Bank Association (HBA) is the institutional representative of the vast majority of all Greek and foreign credit institutions that operate in Greece. HBA, also Full Member of EBF, recognizes the special interaction between the financial literacy of citizens and their level of prosperity. Thus, HBA develops and promotes a variety of programs ${ }^{9}$, mostly targeting students/pupils (8-17 years old), who are the most sensitive, and at the same time, the most dynamic and promising group of the society.

In cooperation with the Ministry of Education, HBA has been running, since 2018, the Hellenic Competition on Money, which is the first stage for the European EMQ Competitions. Taking full advantage of the innovative learning activities and digital EMQ toolkit that was created by FEPG EBF, HBA has been able to reach schools all around Greece as the educational material is simultaneously available to every school regardless of its location. Moreover, the special dedicated section on HBA website ${ }^{10}$ and Kahoot platform provides all day access to the material for everybody (teachers, pupils, parents) while information can be/and are rapidly updated.

9 For more information visit: https://www.hba.gr/info/FinancialLiteracy 10 https://www.hba.gr/info/emq
Adequately, the use of live-streaming option for concluding the National Finals provides a sense of equal opportunity to all pupils regardless if they come from dispersed and isolated areas or from big cities. This feeling is actually the secret ingredient for the continuous pupil's commitment to the EMQ project. As it can be seen in the table below the participation of schools is increasing rapidly every year and the added value is that $50 \%$ of participation comes from schools in the periphery and not only Athens (the capital) covering equal geographical representation of Greek territory. An interesting evidence is also the fact that despite the severe lockdown measures and three months closure of schools due to the pandemic, the schools that participated in 2020 National EMQ covered 7 out of 9 geographical regions of Greece ${ }^{11}$, while the reason for the withdrawal of some schools in the National Finals was caused by the imposition of extra locality restriction measures by the Government.
11 The schools came from Central Greece, Macedonia, the Peloponnese, Thessaly, Epirus, the Aegean Island and Crete. 
Table 3. EMQ in Greece

\begin{tabular}{lllll}
\hline Year & Date & Classrooms & Schools & Pupils engaged \\
\hline 2018 & 13.03 & 53 & 16 private and 9 public & 500 \\
\hline 2019 & 27.03 & 86 & 17 private and 12 public & 1500 \\
\hline 2020 & $03.06^{*}$ & $72^{* *}$ & 17 private and 16 public & 1100 \\
\hline
\end{tabular}

* This year, due to the pandemic, the date of the National finals was transferred 3 months later according to schools' request.

** Initial Participation was 109 classrooms, but only 72 classes competed during finals.

Source: HBA

EMQ is not the only project of HBA concerning financial literacy, but definitely is the one that during the Covid-19 pandemic proved to be really adjustable and resilient to the current circumstances. The use of EMQ digital tools helped to overcome physical restriction measures and facilitated the immediate integration to the school distance learning activities so that financial education remains an ongoing process. In addition, financial literacy is not just a 'need' but a 'necessity' for everyone especially in difficult and unexpected times.

\section{CONCLUSION}

Financial literacy is recognized as an essential life skill (G20, 2012, OECD/INFE, 2012), and according to 2005 Recommendation of OECD 'financial education should start at school. People should be educated about financial matters as early as possible in their lives' (OECD, 2005). Also, research suggests that children form their financial habits as young as seven years old (Whitebread and Bingham, 2013) influenced throughout their childhood by different variables. Young people adopt new technology rather quickly, so we can even consider them as "digital natives". But just having the ability to properly use technology and devices does not protect them when using digital payments on their phones, purchase mobile credit, and use mobile credit for online gaming and in-app purchase (OECD/G20/GPFI, 2020). As such, acquiring new financial skills and competencies is a necessity for young people. Many international organizations and financial sector institutions are dedicated to this field, which is also recorded in a growing number of policies, reports, and projects (e.g. OECD, EBA, EBF). If students can be taught financial responsibility from a young age, it will equip them with a skill they can use throughout their lives. Examples of the EMQ and its national implementations throughout Europe, is bringing positive improvements and good practice at both European and national levels.

\section{LITERATURE}

EBA (2020). EBA Report on Financial Education 2019/2020. Retrieved from: https://eba.europa.eu/sites/default/ documents/files/document_library/News\%20and\%20
Press/Press\%20Room/Press\%20Releases/2020/EBA\%20 identifies\%20trends\%20and\%20lessons\%20learned\%20 in\%20financial\%20education\%20and\%20literacy\%20initiatives\%20in\%20its\%20second\%20Financial\%20Education\%20Report/EBA\%20Financial\%20Education\%20Report\%202019-2020.pdf. Accessed on September 3rd, 2020.

G20 (2012). G20 Leaders declaration. Retrieved from: http:// www.g20.utoronto.ca/2012/2012-0619-loscabos.pdf. Accessed on September 1, 2020.

Koszalka, T. \& Ntloedibe-Kuswani, G. (2010). Literature on the safe and disruptive learning potential of mobile technologies. Distance Education and Mobile Learning, 31(2), 139-157

Liu, M., Navarrete, C. C., \& Wivagg, J. (2014). Potentials of mobile technology for K-12 education: An investigation of iPod touch use for English Language Learners in the United States. Educational Technology \& Society, 17 (2), 115-126.

Neha, Arora (2016). Using Digital Technology to Teach Financial Literacy in Elementary Schools. Retrieved from :https://tspace.library.utoronto.ca/bitstream/1807/72146/1/ Arora_Neha_201606_MT_MTRP.pdf . Accessed September $13^{\text {th }}, 2020$.

OECD (2005). Improving Financial Literacy: Analysis of Issues and Policies. OECD, Paris.

OECD (2005). Recommendation on Principles and Good Practices for Financial Education and Awareness. http:// www.oecd.org/daf/fin/financial-education/35108560.pdf

OECD (2018). Digitalization and Finance. Financial Markets, Insurance and Pensions. OECD, Paris.

OECD/INFE (2012). High-Level Principles on National Strategies for Financial Education.OECD. Retrieved from: hhtp://oecd.org/daf/fin/financial-eduction/OECD-INFE-Principles-National-Strategies-Financial-Education. Accessed on September 15 $5^{\text {th }}, 2020$.

OECD (2014). PISA 2012 Results: Students and Money. Financial Literacy Skills for the $21^{\text {st }}$ century. Volume VI, PISA, OECD Publishing.

11. OECD/G20/GPFI (2020). Advancing the Digital Financial Inclusion of Youth. Report prepared for the G20 Global Partnership for Financial Inclusion by the OECD.

12. Whitebread, D., Bingham S. (2013). Habit Formation and Learning in Young Children, The Money Advice Service, Cambridge. Retrieved from http://www.moneyadviceservice.org.uk/en/corporate/habit-formation-and-learningin-young-children. Accessed on September $3^{\text {rd }}, 2020$. 